\title{
The role of headmater to improve the quality of education in 4 state basic schools in kecamatan air kumbang
}

\author{
Rina Puspita Sari ${ }^{1}$, Happy Fitria ${ }^{2}$, Achmad Wahidy ${ }^{2}$ \\ ${ }^{1}$ Sekolah Dasar Negeri 9 Air Kumbang, Indonesia \\ ${ }^{2}$ Universitas PGRI Palembang, Indonesia
}

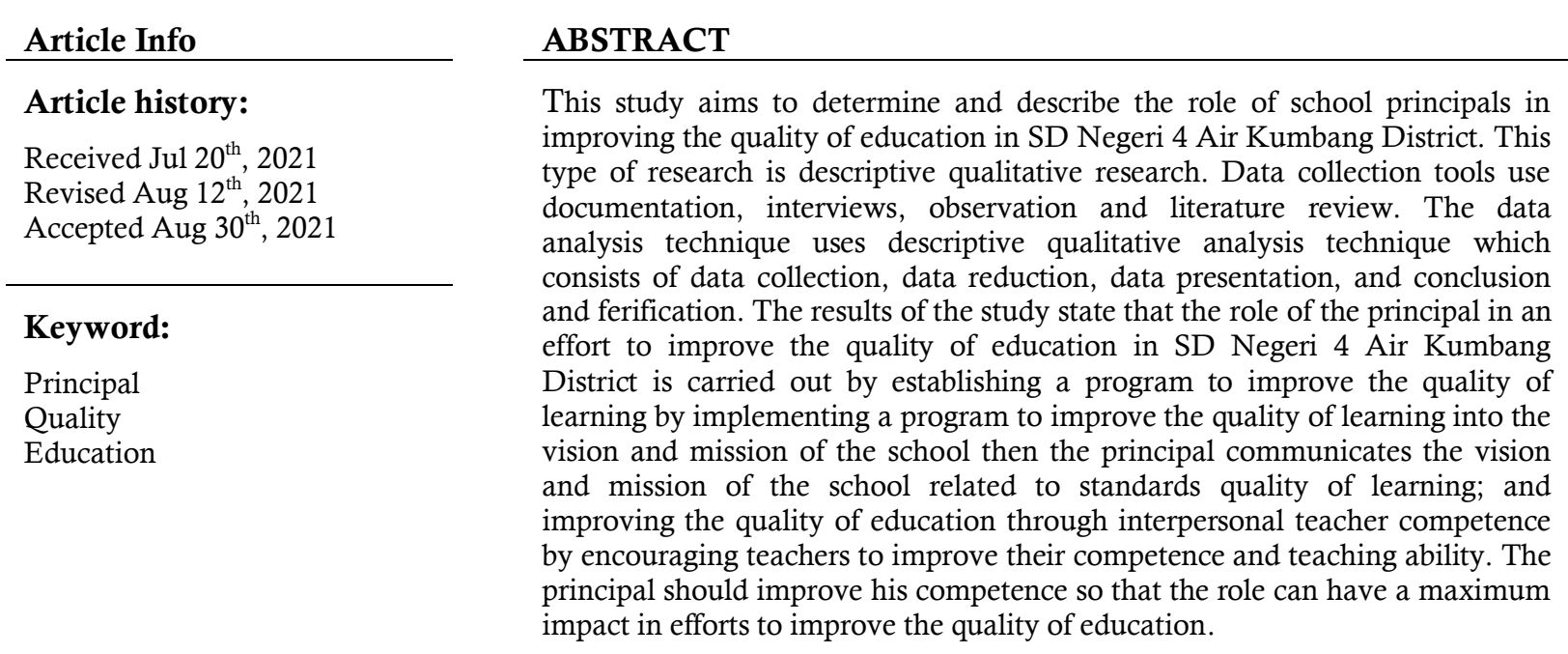

(C) 2021 The Authors. Published by IICET.

This is an open access article under the CC BY-NC-SA license

(https://creativecommons.org/licenses/by-nc-sa/4.0

\section{Corresponding Author:}

Sari, R. P.,

Sekolah Dasar Negeri 9 Air Kumbang, Indonesia

Email: rinapuspita031@gmail.com

\section{Introduction}

Indonesian education is faced with various challenges, both internal challenges and external challenges. The internal challenge is that many schools have not met the eight National Education Standards. Meanwhile, the external challenge is globalization, which has penetrated all aspects of people's lives. Therefore, [1] Education is very important as one of the determinants of the quality of human resources because today the excellence of a nation is no longer identified with the abundance of natural resources available, but rather the excellence of its human resources, because the quality of human resources contributes positively. for the quality of education [1]

In accordance with the above challenges, efforts to improve the quality of education must continue to be made by various parties in the context of developing human resources and developing national character. As stated by [3] improving the quality of education is a development target in the national education sector and is an integral part of efforts to improve the overall quality of Indonesian people.

Therefore, a quality education process can be carried out if members of educational institutions work optimally, have commitment and aretiqamah in their work. Therefore, the principal as an important factor and 
supports the progress of an educational institution is expected to determine the direction of policy in educational institutions. As the manager of an organization the principal regulates all matters related to organizational life. As a consequence of the implementation of improving the quality of education, adequate leadership from the principal is needed in managing schools and managing educational human resources. As the results of research conducted by [3] oversee output, PBM, and students from the admission process to completion of school.

In an effort to improve the quality of education, the principal should understand, master and be able to carry out activities related to his duties as education manager. The quality of education is very dependent on the management of education that has a good plan, so that each implementation of these activities has a clear objective. [4] quality schools are influenced by a quality education process with supporting factors, adequate facilities and infrastructure and costs, proper management, and a supportive environment. Based on the above opinion, it can be explained that the principal has a big responsibility for improving the quality of education in schools.

In particular, in the standard of the learning process as the core of educational activities, the principa must be able to carry out his role in improving teacher abilities, because teachers are in direct contact with the learning process. Another problem is that schools have not been able to utilize facilities and infrastructure to improve the quality of the learning process where the limited budget for providing learning infrastructure at SD Negeri 4 Air Kumbang District has an impact on the teaching and learning process is not optimal. In addition, the principal is still not maximal in providing maximum guidance, coaching and supervision to teachers to make improvements to problems related to the implementation of learning.

In addition to the above problems, there are still a number of other problems faced by the principal at SD Negeri 4 Air Kumbang, namely the existence of errors in the assignment of educational personnel such as placing someone who is not an expert so that their duties are not maximal, besides the lack of courage of the principal to propose improvements facilities and infrastructure that support the smooth process of teaching and learning activities, then coordination between school principals and educators and education personnel. Sometimes there are differences of opinion, causing inconvenience in carrying out tasks.

In addition, problems related to the standard of the learning management process at SD Negeri 4 Air Kumbang Subdistrict were found several problems including the absence of a continuous training program that can be followed by all teachers, especially in applying the 2013 curriculum totally in the learning process. This can be seen from some teachers who have designed learning plans using the 2013 curriculum, but in the teaching and learning process they still use semi-conventional methods, where the teacher looks more active than students, even though occasionally students are given the opportunity to ask and answer questions.In order for this to be achieved properly, the leadership of the principal needs to carry out its role in accordance with the duties, authorities and responsibilities [5].

[6] The principal must encourage all teachers to work totally in educating their students, have a vision for school progress, be consistent with their vision, but remain democratic and respect the views of the staff. The principal must also have good expectations of his students, provide strengthening basic skills for his students, so that they can develop well in any profession, and be able to create a conducive atmosphere for teachers and employees and create a comfortable atmosphere for students [6].

Based on the explanation above, the authors feel it is important to know and analyze how the role of the principal in improving the quality of education in SD Negeri 4 Air Kumbang District. Therefore, the authors are encouraged to conduct research with the title Role of the Principal in Improving the Quality of Education in SD Negeri 4 Air Kumbang District.

Principal comes from two words, namely head and school. the word head can mean the chairman or leader in an organization or an institution. Meanwhile school is an institution where it is a place to receive and give lessons. [7] the Principal is a functional teacher who is given the task of leading a school where a teaching and learning process is held, or a place where interactions occur between teachers who give lessons and students who receive lessons. As for the role of the principal as the leader of the institution, namely (1) the principal as an educator (educator); (2) the principal as a manager (manager); (3) the principal as Supervisor; (4) the principal as a leader (leader); (5) the principal as an innovator; (6) the principal as a motivator [1]. The principal's authority as a leader to achieve school goals is to regulate and manage three main things, namely personnel, facilitie and funds. As a manager, the principal must be able and have adequate management capabilities to carry out his duties. [9] This ability is very supportive when managing personnel or human resources owned by the school. 
In the context of education, according to the Ministry of National Education in [2] the notion of quality includes the input, process and output of education. Education input is something that must be available because it is needed for the progress of a process. Meanwhile, the educational process is a change from something to something else. Furthermore, educational output is school performance, namely school performance resulting from school processes and behavior. Therefore, the quality in the world of education can be stated to put more emphasis on student success. In other words, school improvement programs are carried out more creatively and constructively [2].

\section{Method}

This research was conducted at SD Negeri 4 Air Kumbang District. The research was carried out from November 2020 to December 2020. This research used descriptive qualitative methods. [11] mentions qualitative research as a research procedure that produces descriptive data in the form of written or spoken words from people and observable behavior, where the method used emphasizes the process of searching for data / information until it is felt that it is sufficient to make an interpretation. Data collection techniques in this study using observation, interview and documentation techniques. This is based on the opinion of [12] that the success of a naturalistic research depends on the accuracy and completeness of notes compiled through observation, interviews, documentation and literature study. The data that has been obtained will be processed using qualitative research, then conduct a domain analysis to obtain a general and comprehensive description of the object of research through the process of data reduction, display and verification [13]. [14] states that the validity test in qualitative research includes testing data credibility (internal validity), transferability (external validity), defendability (reliability), and confirmavibility (objectivity).

\section{Results and Discussions}

Based on the results of the research, it can be argued that the role of the principal in improving the quality of education in SD Negeri 4 Air Kumbang, namely 1) Establishing a program to improve the quality of learning through the vision and mission of the school, among others by implementing a program to improve the quality of learning into the vision and mission of the school then the principal communicates the vision and school mission related to quality standards of learning so that it can be realized in substantive policies in the field of learning. The principal determines the standards for the graduates to be achieved.

In order for these graduate standards to be achieved, the principal organizes learning activities according to the achievement targets. In addition, the school principal also emphasized that the learning evaluation process carried out by the teacher be carried out objectively and continuously; 2) Increase the competence of teachers among all by encouraging teachers to improve their competence and teaching ability. In order for the program of guidance and improvement of teaching skills to run optimally, the principal formed a team consisting of senior teachers as task executors to assist in the implementation of the program; and 3) Creating a conducive school climate, among others, by fostering commitment in implementing learning activities; foster the willingness of all school members to improve quality in a sustainable manner; fostering the participation of school members in creating a safe and orderly environment; realizing good communication; implementing manpower management fosters high expectations of achievement, development and performance evaluation, as well as giving awards for the successes achieved; and implement transparent management and strong accountability.

Through the realization of the vision and mission of the school which clearly describes the ideals of the school so that the principal has a clear direction and picture of the school he leads. From the results of the study states that the instructional leadership of the principal in an effort to improve teacher professionalism through the realization of the school's vision and mission is carried out quite well. The principal of SD Negeri 4 Air Kumbang District communicates the vision of the school so that it can be understood well by the entire school community. The vision of SD Negeri 4 Air Kumbang District emphasizes the importance of quality in learning. Thus the principal has a high attention to the quality of learning.

Based on the research results, it is known that the principal is committed to establishing good cooperation with the entire school community, and is fully aware that it is impossible for the principal to be able to carry out the school's vision alone. [14] states that wise principals understand that they cannot achieve teaching goals alone, without the participation of other parties. Based on observations, it is known that the principal actively involves teachers, staff, and other components in various activities. However, the principal has not been seen to be active in instilling leadership values in learning to teachers and staff, as well as preparing for leadership succession. The principal is committed to running good communication with teachers and staff, 
Based on the research results it is known that the principal is very committed to the quality of learning. However, the efforts of the principal to ensure the quality of learning need to be supported by improving the quality of education. The lack of in-depth understanding of the concept as a learning leader can be seen from the lack of efforts by the principal to implement programs to improve the ability of teachers to learn research-based learning models, the lack of opportunities that allow teacher collaboration in assessing, analyzing, and finding joint solutions to a case of learning. At SD Negeri 4 Air Kumbang District, a long-term school role plan as well as an annual operational plan has been prepared. This is intended so that the process of fostering professionalism for teachers at SD Negeri 4 Air Kumbang District can run continuously.

The coaching material delivered by the Principal of SD Negeri 4 Air Kumbang Subdistrict in routine meetings tries to encourage the teachers of SD Negeri 4 Air Kumbang District to always improve their abilities in the field of insight and educational foundation both regarding learning materials and learning methods and the use of instructional media, as well as increasing the ability of teachers to carry out research. The principal also tries to improve the ability of teachers to operate computers and access data via the internet for learning and research needs. Other than that,

For the implementation of classroom action research training the principal of SD Negeri 4 Air Kumbang sub-district held continuous training activities by inviting external speakers because considering the many stages in studying scientific writing and the ability of teachers to conduct research is still very low. The results of this study are supported by research conducted by [16]. Based on the results of the research conducted, it can be concluded that the efforts that have been made by the teachers of SMAN 1 Kauman to develop professionalism through writing scientific papers as a form of professional development are by participating in training / workshops, independent learning, participating in competitions / tests. Based on the results of this study, it is suggested to the principal to carry out workshops on an ongoing basis, add library reference books, conduct computer training, apply a managerial reward and punishment pattern, control and monitor the implementation of MGMP and control and monitoring. the activities of the teacher performance appraisal team and the development team. ongoing professionalism. Efforts that have been made by the teachers of SMAN 1 Kauman to develop professionalism through writing scientific papers as a form of professional development are by participating in training / workshops, independent learning, participating in competitions / tests.m

To empower students, teachers are expected to be able to understand the characteristics of students, both from physical, moral, social, cultural, emotional, and intellectual aspects. With this detailed understanding, the teacher will guide students by adjusting the conditions of each student, so that the teacher can spur the development of students to optimally actualize the various potentials that students have, which in the end the learning material or activities are well absorbed and their goals reached. In developing teacher competence, it is facilitated by the implementation of a 2013 curriculum development workshop which is followed up by intensifying KKG activities.

In this activity, it will be quite effective for teachers because they can technically study together to compile a syllabus, lesson plans, annual programs and semester programs and other tools. Then in an effort to standardize the assessment system, workshops and implementation of assessment guides are held. This activity is intended so that in the assessment of students there are standard standards, so that in providing an assessment, a teacher can avoid a subjective attitude and be as objective as possible. This is very important to enforce so that the quality of students is really well measured.

[17] one of the conditions for an effective school is that the principal makes every effort to ensure the quality of teaching in his school. The form of principal's attention to the quality of learning through improving the quality of teacher teaching is the implementation of a scheduled classroom supervision program. In the learning process, motivating students, presenting information, stimulating discussion, and directing student activities requires good communication so that learning objectives can be achieved. Likewise in terms of relationships with guardians of students, with school committees, and also with government agencies, that communication plays a very important role. The progress and success of schools is partly due to good communication,

Teacher social competence needs to be developed so that there is a harmonious relationship between teachers and school principals, education staff, students, student guardians and the community. A harmonious relationship will create a comfortable atmosphere in the school environment so that it can positively influence the achievement of school goals. This condition will also affect the public image of the school.

The program for the Principal of SD Negeri 4 Air Kumbang District is an effort to create effective communication and interaction in schools. Forming a smiling attitude, getting used to meeting anyone to give or answer greetings and greetings, develop courtesy, foster a sense of brotherhood and a spirit of togetherness 
are efforts that must always be made to achieve a better school environment. This is in line with Basri's opinion that one of the principal's duties is to convince teachers of the need for changes to better conditions. The homeroom teacher leads the guardianship meeting held according to mutual agreement and receives consultation from the guardians of the students, especially regarding the development of student learning,

The ability of teachers to apply means of communication and information technology is always honed through school programs that function as a means of communication and information between schools. With the provision of this activity facility, the Principal of SD Negeri 4 Air Kumbang District hopes that all SD Negeri 4 Air Kumbang District teachers can adapt to technological developments.

To meet the standards of professional competence, the Principal of SD Negeri 4 Air Kumbang District has made efforts by sending teachers to attend Teacher Professional Education and Training for teachers who have met the requirements. As well as all teachers of SD Negeri 4 Air Kumbang District in training activities conducted by schools and outside of school. Therefore, the principal of SD Negeri 4 Air Kumbang District ensures that the Teacher Working Group runs routinely and effectively, with KKG activities that run regularly and effectively, it is hoped that teachers will get coaching, training, and exchange ideas, share experiences and information in an subjects in accordance with the demands of the development of science and technology.

\section{Conclusions}

The principal in an effort to improve the quality of education at SD Negeri 4 Air Kumbang District is carried out by establishing a program to improve the quality of learning through the vision and mission of the school among others by implementing a program to improve the quality of learning into the vision and mission of the school then the principal communicates the vision and mission of the school related to the school's vision and mission. learning quality standards so that they can be realized in substantive policies in the field of learning. The principal determines the standards for the graduates to be achieved. In order for these graduate standards to be achieved, the principal organizes learning activities according to the achievement targets. This research has implications for scientific development in theory with regard to the role of school principals and efforts to improve the quality of education.

\section{References}

Fitrah, M. (2017). Peran kepala sekolah dalam meningkatkan mutu pendidikan. Jurnal Penjaminan Mutu, 3(1), 31-42.

Mulyasa. (2013). Pengembangan dan implentasi pemikiran kurikulum. rosdakarya bandung.

Rosyadi, Y. I., \& Pardjono, P. (2015). Peran kepala sekolah sebagai manajer dalam meningkatkan mutu pendidikan di smp 1 cilawu garut. Jurnal Akuntabilitas Manajemen Pendidikan, 3(1), 124-133

Sukmadinata, N. S (2010). Pengembangan Kurikulum Teori dan Praktek.Bandung:PT. Remaja Rosdakarya

Purwanti, K., Murniati, A.R. dan Yusrizal. (2014). Kepemimpinan Kepala Sekolah Dalam Meningkatkan Kompetensi Guru Pada SMP Negeri 2 Simeulue Timur. JurnalIlmiah Didaktika XIV(2), 390-400.

Rosyada, D. (2013). ParadigmaPendidikan Demokratis, Sebuah ModelPelibatan Masyarakat DalamPendidikan. Jakarta: Prenada Media.

Wahjosumidjo, (2012). Kepemimpinan Kepala sekolah. Jakarta: PT Raja Grafindo Persada.

Daryanto. (2011). Model Pembelajaran. Bandung: PT Sarana Tutorial NuraniSejahtera

Saroni, M. (2016). Manajemen Sekolah: Kiat Menjadi Pendidik yang kompeten. Jogjakarta: Ar-Ruzz.

Zahroh. A. (2014). Total quality management (Teoridan praktek manaje menuntuk mendongkrak mutu pendidikan). Yogyakarta: Ar-Ruz Media.

Moleong, L, J. (2011) Metodologi Penelitian Kualitatif, Penerbit PT Remaja Rosdakarya.

Fauzan,A., dan Djunaidi,G. (2012). Metodologi Penelitian kualitatif, JogJakarta: Ar- Ruzz Media

Miles and Huberman, (2013). Analisis Data Kualitatif Terjemahan oleh Tjetjeb Rohendi Rohandi. Jakarta : Universitas Indonesia.

Sugiyono. (2011). Metode Penelitian Kuantitatif dan R dan D, Bandung : Alfabeta.

Hargreaves, A. (2017). Sustainable professional learning communities. Professional learning communities: Divergence, depth and dilemmas, 181-195

Noorjannah,L. (2014). Pengembangan Profesionalisme Guru Melalui Penulisan Karya Tulis Ilmiah Bagi Guru Profesional Di Sma Negeri 1 Kauman Kabupaten Tulungagung. Jurnal Humanity ISSN 02168995 volume 10 no. 1 hal. 100 
Stronge, JH. (2017). Qualities of Effective Teachers (2nd edition). Alexandria: Association for Supervision and Curriculum Development 